Route List $r^{2}{ }^{2}-4$.

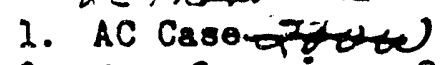

2. $4 C$ foot $108 \%$

3. A.C.CASE 12498

$11-29-12$

$108 F$
FILE

DATE

SUBJECT Methods of Assaying for Putonium

5.

COPY No. 54 AC Case

BEFORE READING THIS DOCUNENT, SIGN ANO DATE BELOW:

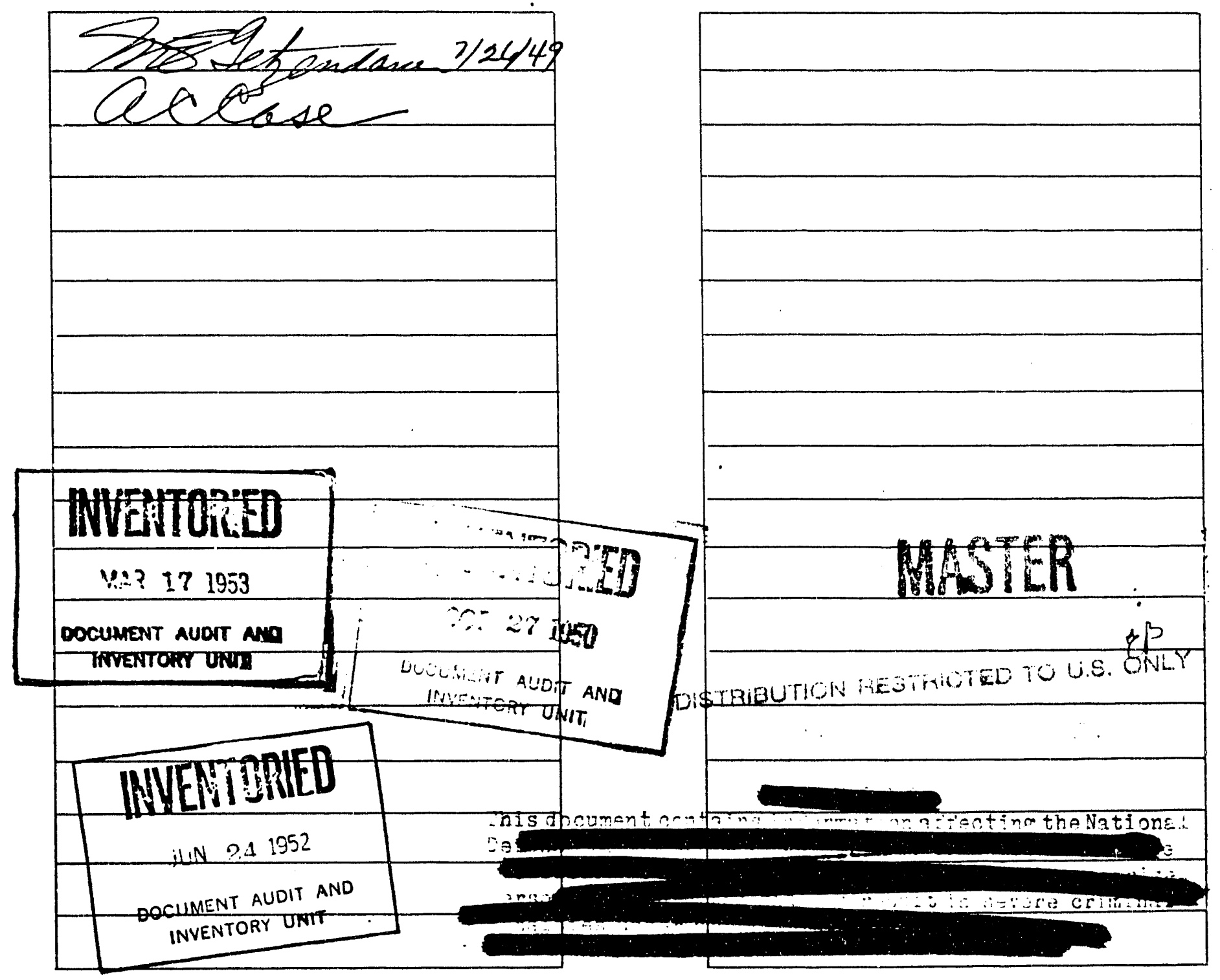




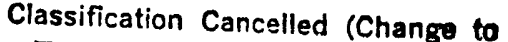

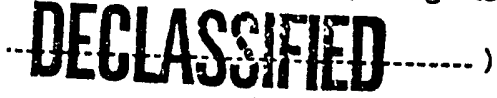

By Authorr:y of. . .1.0.-L.11.2.

Pouge $2383-15 \cdot 13$ 8y S.toke $11-29.56$

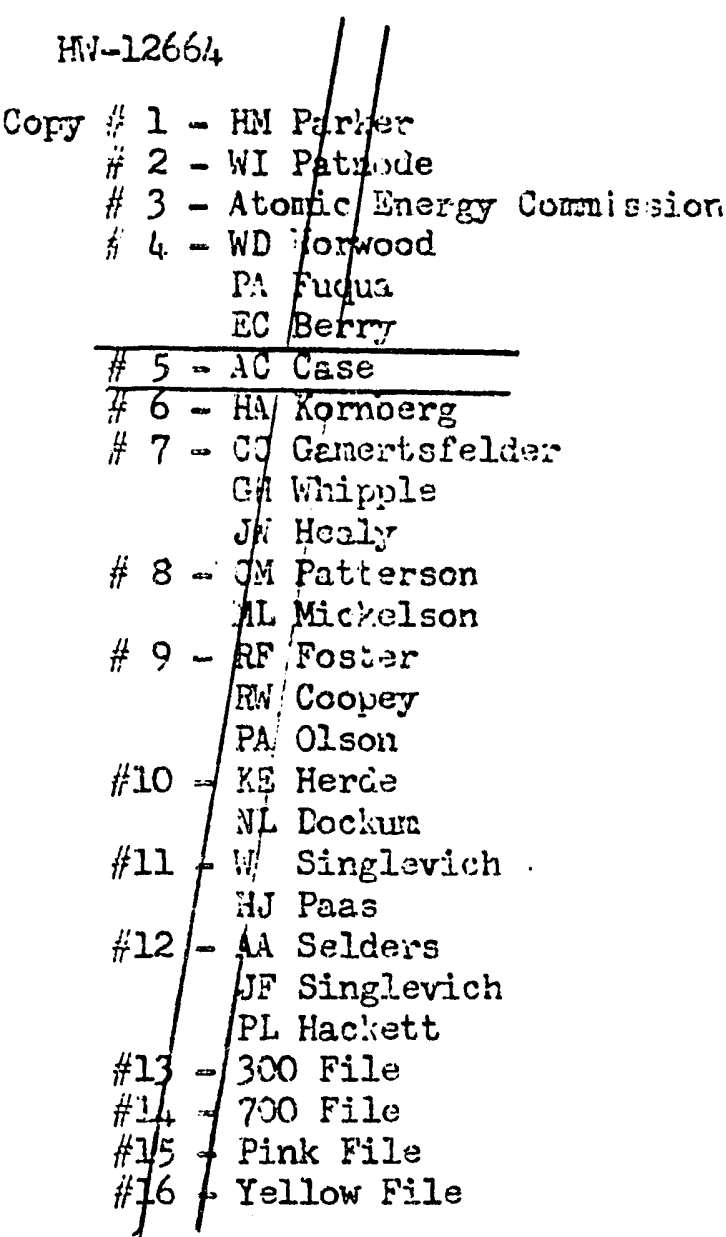

Noveraber 16, 1948

\section{BIOIOC: SEMINAT}

This Document consists of

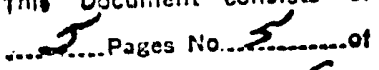

Copies, Series _ares

METHODS OF ABSAYING FOR PLUIONIUM IN BIOLOGICAL MATERIALS

by A. C. Case

Biv...cgy Division

Health Instrument Divisions

General Eiectric Company

Hanford Vorks

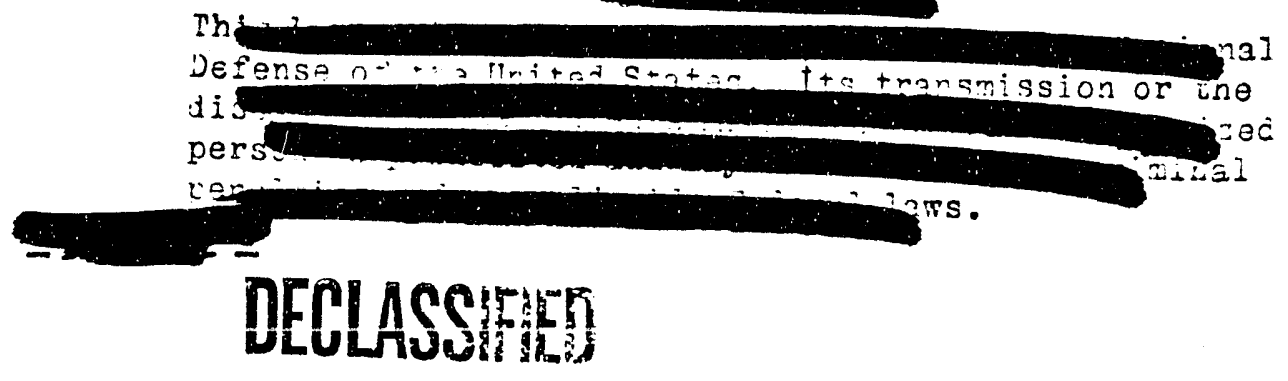




\section{INTRODUETICN}

Since plutonium is inanufaciurad at the Haniord Works, a study of its effect on biological materials is important. To determine the amount of plutonilim deposited in a biological sample, it is necessary to have and accurate rethod for extracting plutonium from these samples. Some of the different methois roi piutonium assa.j are reviewed and given in this parer.

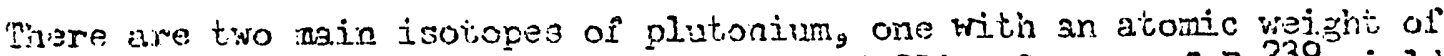
238 and the outher with an atomic weight of $23 \%$. Dne $\mu$ of Pu239 jields 238 and the other with an atomic weight of $23 \%$

$\therefore$ be fourd in several velence states. These are $0,42,43,44,65$, and fio. The 0 state is the metallic forn. The fit state is not found in solutions. The black tamish on the free metal is thought to be Put. plutonium in the fy state is easily axidiosd to higher valences by air or othex oxidants which in high concentrations is a bluesviolet color wher in solutior. The state is the colrcon one found in aqueous solutions. Plutionium in the ph stete is unstable and is prociuced by controliea eleatrolytic or chenicai reduction of the $f 6$ state. The highest, valence state found is 26 . Plutonium solutiors should be kept, acid since it tends to adsorb out on the glass containers in neutral or alkaline media.

\section{MDTHDS OF ASSAY}

A, Meterials of High Specific Activity

For these samples, it is of ten satisfactory to put the sample into sciution in acid, and dry an 2 liquot on a stainless steel plata. The amount of solid left on the plate mugt be kept at a minitum to rerluce the self absorption.

B. Naterials of Low Specific Activity

These sanples are ashed first to remore the organic matter. This can be done by the dry method (mufling), the wet method (witi fuming $\mathrm{HNO}_{3}$ and $\mathrm{H}_{2} \mathrm{O}_{2}$ ) or a combination of the two. A further corcentration of tile plutoniun from the remaining inorgaric salts is decired belore counting. The following are some of these concentretting methods.

1. Cupierron-chloroform Methud (1)

Cupferron and chloroform have been used on plutonium spiked urine samples. This is done by mixing cupferron with the urine, followed by a chloroform exiraction. The chlorofora containing plutonium was evaporated on a plate for counting. The percent recovery was quite variable and nct too high. Also the interface between the $\mathrm{CHCl}_{3}$ and the urine was illdefined, malcing good separation difricult.

2. Resins Meihod $(2,3)$

Various resins have been used to try to concentrate plutonium from urine samoles. Both coium and batch extractions have been tried. Often a gelatinous precipitate plugged the column.

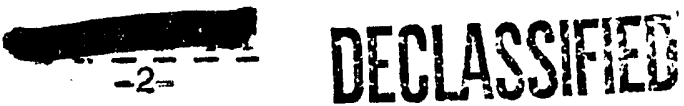




\section{DECLASSIFIED

E.V- -12664

The batch method is to stir the urine with the resin, decant the liquid, and wash the resin into a funnel. The plutonium is remored with $6 \mathrm{~N} \mathrm{HCl}$. Water spikes give fair results, but urine samples give low and non-reproducib's percentages, even when identical conditions are met.

3. Ianthanum Fluoride Method (2)

Several "carriers" may be used which, when they are prectpitated, will carry along the plutonium. One such method uses $\mathrm{InF}_{3}$. The process is to add the lanthanum ion, and precipitate with HF. Then spread, dry, and count the precipitate. Recovery is quite good for small samples of at least moderate activity. Calcium also forms a precipitate under these conditions and hinders the determination in bone samples.

1. Bj.smuth Phosphate Method $(1,2)$

An extension of the above method is to precipitate bismuth carrier with phosphoric acid followed by dissolving the precipit tte in $2 \mathrm{~N} \mathrm{HCl}$ and performing a lanthanum fluoride procecure on the solution. Closely controlled conditions give recoveries of about $80 \%$ for small urine samples of high activity.

5. Zirconium Phosphate Method $(1,2,4,5)$

It is also possible to precipitate zirconium carrier with phosphoric acid, dissolve, and follow with a lanthanum flucride procedure. This is often done on bone sampies where there is 2 high calcium content. The method gives about $80 \%$ recovery on $25 \mathrm{cc}$ spliked urine samples.

6. Hexcone Method (6)

Hexone (isobutylmethyl ketone) can be used to concentrate plutonium. A preliminary precipitation with lanthanum carrier and HF is first performed. The precipitate is dissolved and the plutonium extracted into a hexone layer. Re-extraction into a water layer, followed by another lanthanum fluoride precipitation finishes the procedure. $75 \%$ of the original activity goes into the hexone layer with one extraction.

7. TTA Method $(7,8,9,10)$

The TTA (thenoylatrifluoroacetone) method is the one used here at Hanford for the analysis of urine samples. TTA is one of several trifluorinated compounds which complex plutonium in the $\$ 4$ valence, making it extractable into a non-polar solvent such as benzere. The procedure is first to carry out a lantranum fluoride precipitation. This is dissolved in an $\mathrm{AI}\left(\mathrm{NO}_{3}\right)_{3}$ solution, and extracted with a benzene solution of TTA. This ay be evaporated directly to stainless steel plates, or a re-extraction into $8 \mathrm{~N} \mathrm{HNO}_{3}$ maybe performed, and the HNO3 $_{3}$ evaporated. Advantages of this method are the neglizible amounts of maiter left on the plates, and the removal of most of the alpha contamination present in lanthanum. Results on hater spikes and small samples of urin., feces, tissue, etc. are $90-99 \%$ recovery.

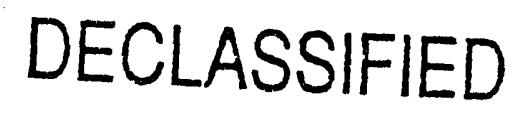




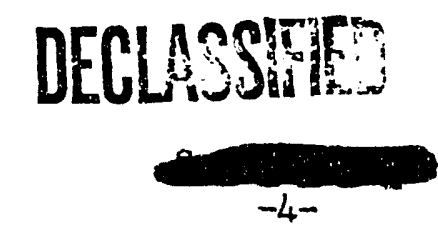

HW -22664

\section{SUMAARY.}

The cholce of a method to use depends upon the conditions and facilities available. Both the cupferron and resins methods prove unsatisfactory, especially for urine samples. The $\mathrm{LaF}_{3}$ method is short and quite satisfactory for small samples of low calcium content with fairly high specific activity. The bissuth phosphate and zirconium phosphate methods try to remove the difficulties encountered with samples of high calcium content. These procedures are longer and demandmore exacting conditions. The hexone method is also long, but not too difficult. The TTA process has an advantage that a very small amount of matter is left on the plates. It is also fairis easy to carry out. 


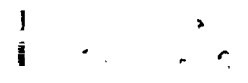

DECREE

$H W-12664$

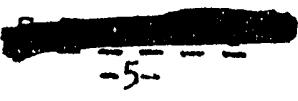

BIBLTOGRA PHI

1. Nickson, J.J., Monthly Report on Health Pro'Iems Relating to Product", CN 2312, October 31, 1944.

2. Nickson, J.J., "Monthly Report", CN 2458, November 30, 1944.

3. Morris, "Experiments with Urinalysis by Resin Absorption", 3-3243, November 20, 1945.

4. Russell, "Monthly Report", CN 2740, February 1945.

5. Tinkle, and others, "The Toxicity and Metabolism of Plutonium in Laboratory Animals", $\mathrm{CH} 3783$, August 1946.

6. Scott, K.G., "Hexone Method of Product Separation from Human Urine and Feces", 7226, June 9, 1945.

7. Thomas, J.R. and Cranial, H.W., "The Chelate Process", A 3964, no date.

- 8. Scott, K.G., "Procedure for TTA Method", 7309, July 13, 1945.

9. Parker, H.M. and Mealy, J.W., "Report on VIsit to Cracker Radiation Laboratory at Berkeley", 7-2978, December 3, 1945 .

10. Heal, J.W., "Status of Urine Analysis for Plutonium at HEW.n, 3-3443, March 1, 1946.

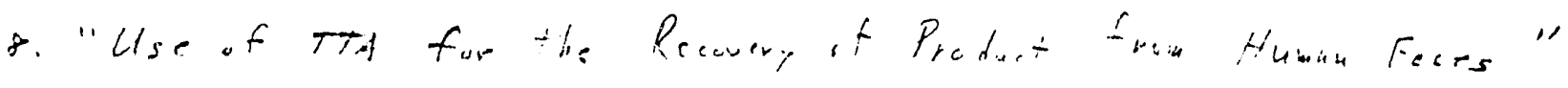

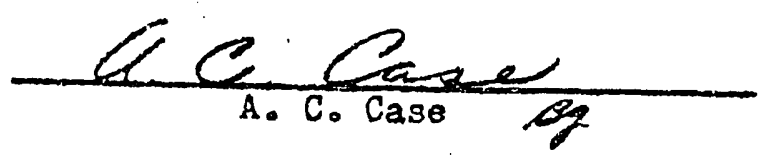

bo

DECLASHED 

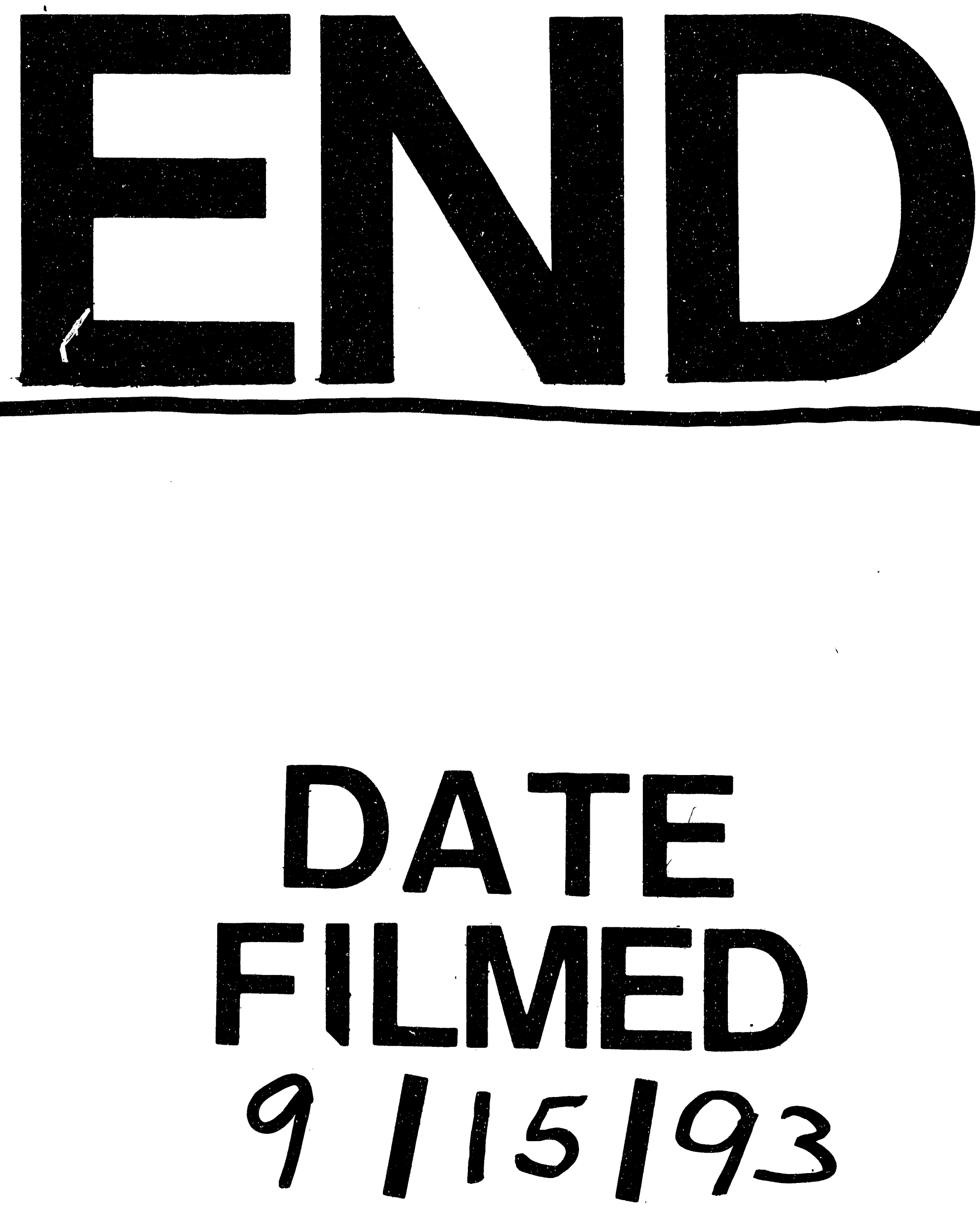
